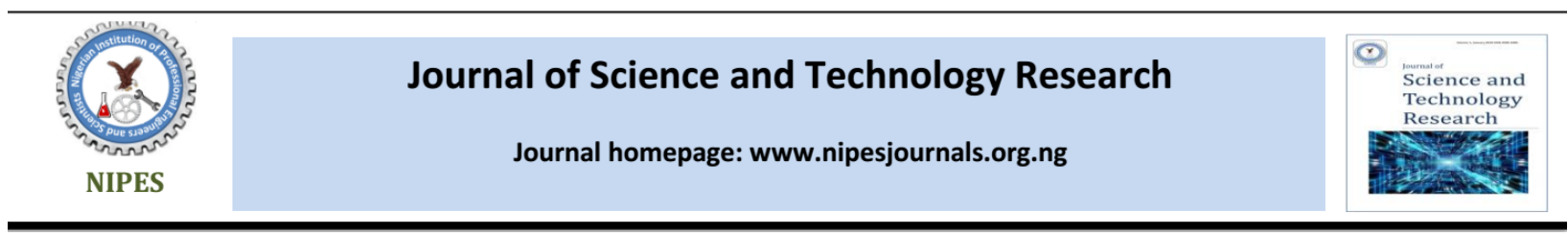

\title{
Assessment of the Antimicrobial Sensitivity of Ethanolic Extracts of Phyllanthus amarus (Schum. et Thonn) Leaves on Oral Microorganisms
}

\section{Oshomoh, E. O.*, Uzama-Avenbuan, O. and Ayanru, D.}

Department of Science Laboratory Technology, Faculty of Life Sciences, University of Benin. Edo State. Nigeria *Corresponding Author: Oshomoh, E. O. E-mail: emmananuel.oshomoh@uniben.edu; Tel: 08055452141

\section{Article Info}

Received 04 June 2020

Revised 18 June 2020

Accepted 18 June 2020

Available online 31 August 2020

Keywords:Phyllanthus amarus; antibacterial, anti-fungal, sensitivity, ethanolic extract

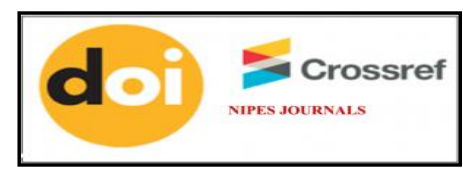

https://doi.org/10.37933/nipes/2.3.2020.10

https://nipesjournals.org.ng (C) 2020 NIPES Pub. All rights reserved.

\begin{abstract}
Herbs are used in the treatment of several human ailment and diseases. One of such herbs which have always been used for the treatment of human diseases is Phyllanthus amarus. The antimicrobial sensitivity of ethanolic extracts of Phyllanthus amarus leaves on oral microorganisms was determined. The ethanolic leaf extract was tested for antimicrobial activity using some clinical isolates such as E. coli, Klebsiella sp, Pseudomonas sp, Citrobacter sp, Bacillus sp and Staph. aureus, showed sensitivity of $15.3333 \mathrm{~mm}$ at a concentration of $100 \mathrm{mg} / \mathrm{ml}$ followed by Klebsiella and Bacillus with sensitivity of $14.0000 \mathrm{~mm}$ and $14.0000 \mathrm{~mm}$ respectively at 75 $\mathrm{mg} / \mathrm{ml}$. while the least antibacterial sensitivity of $7.0000 \mathrm{~mm}$ was recorded at a concentration of $3.125 \mathrm{mg} / \mathrm{ml}$. The leaf extract also showed higher antifungal inhibitory activity in some fungi species such as Penicillium and Sacchromyces. This indicates that the plant contained some bioactive compounds with antibacterial, antifungal and skin conditioning properties.
\end{abstract}

\section{Introduction}

Phyllanthus amarus (schum. et thonn), of the family Euphorbiaceae, consists of species of about 6500 in 300 genera, of which about 200 are American, 100 are African, 70 are Madagascar and the remaining are Australian and Asian [1]. Many species belonging to this family are native to South, Central and North America. The name 'Phyllanthus' refers to "leaf and flower" because the flower and fruit seems to become one with the leaf [1].

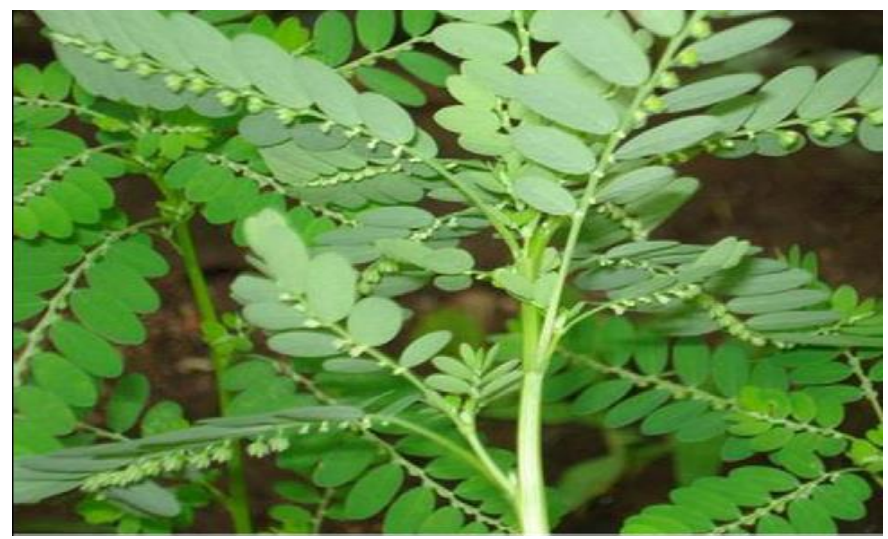

Plate 1: Phyllanthus amaru plant [2] 
Biological active compounds in plants have always been of immense awareness to scientists who work on infectious diseases. In recent years, many have developed growing interest to evaluate leaves that possess antibacterial activity for various diseases. Reports have been made on a number of studies on antimicrobial screening of extracts of medicinal leaves. It is now estimated that constituents in leaves exist in, or have provided the ideal for about $50 \%$ western drugs. Countless number of these drugs that are now used commercially in present day medicine was originally used in crude form in the old or folk treatment of many infections, or for other purposes that suggested potential use of biological activity [3].

$P$. amarus is now widely used because of its novel antiviral activity against hepatitis B virus and other numerous viral infections; jaundice, liver cancer, liver diseases and disorders; and for several other biological activities like tuberculosis, gallbladder and kidney stones, also used for cold and flu [4]. The extracts of Phyllanthus amarus are good antioxidant, along with antibacterial potential, predominantly, in conditions such as diarrhoea, blennorrhagia, colic, dysentery, dropsy, running nose, winter common colds, indigestion, alternating fevers, hepatitis, and malaria [5, 6].

$P$. amarus as herb has been used traditionally for the treatment of many health problems such as recurrent fevers, diabetes, dropsy, jaundice, urinogenital disorders, scabies, wounds, kidney problems, urinary bladder disturbances, pain, diarrhoea, gonorrhoea, dysentery, and chronic dysentery [7]. It is used for the treatment of several skin problems such as skin ulcers, ringworm, swelling and itchiness, crusty lesions wounds, bruises, ulcers and sores, edematous swellings, sores, tubercular ulcers, scabby and scabies [8].

$P$. amarus as a rebuilding herb is used as an appetizer, tonic and as colic. The plant is considered to be a diuretic when boiled with the leaves and used in curing dysentery, menstrual disorders, hepatitis, diabetes, and skin disorders [9]. Plant extracts are used to purify blood against mild fevers, malaria and anaemia and helps to discharge phlegm. The herb can also be used to get rid of constipation [9]. This current study is aimed at investigating the antimicrobial sensitivity of ethanolic extract of $P$. amarus leaves on oral microorganisms.

\section{Methodology}

\subsection{Collection of Plant Material}

The plant sample of Phyllanthus amarus was obtained from the vicinity of University of Benin and identified by Dr. H.A. Akinnibosun of the Plant Biology and Biotechnology Department, University of Benin. Benin City, Nigeria.

\subsection{Preparation of Plant Sample}

The plant sample was thoroughly washed in clean water and air dried at room temperature for several days. It was oven dry at $40^{\circ} \mathrm{C}$ for 24 hours and ground into fine powder. The ground sample was then weighed for extraction.

\subsection{Extraction procedure}

About two hundred and sixteen eight grams (216 g) of the ground leaves was exhaustively extracted with 500ml of ethanol using a Soxhlet extractor equipped with a reflux condenser for about 8 hours. The extract was concentrated using rotary evaporator on a water bath $\left(50 .{ }^{0} \mathrm{C}\right)$ to give the crude extracts.

\subsection{Antimicrobial Susceptibility Test}

The antimicrobial susceptibility test was determined using agar well diffusion method with nutrient agar (NA) and potato dextrose agar (PDA). The freshly prepared and cooled media were poured into petri dishes. The petri dishes were placed on a horizontal surface to give a uniform depth of 
approximately $7 \mathrm{~mm}$, . The agar media were allowed to solidify at room temperature, and overnight cultures of the tested microorganisms were evenly applied on the surface of dried agar plates. Three (3) wells of $4 \mathrm{~mm}$ diameter were bored on the solid agar aseptically using a sterile cork-borer and were labeled accordingly from 1-10 which corresponded with the code numbers of the organisms, extracts and control. The plates were left to allow the extracts pre-diffuse into the agar for at least 30 minutes after which they were incubated at $37^{\circ} \mathrm{C}$ for 24 hours for bacteria and 72 hours for fungi. Ketoconazole was administered as a positive control to ascertain the susceptibility of the fungi to different concentrations of the extract. Ciprofloxacin was administered as a positive control to ascertain the susceptibility of the bacteria to different concentrations of the extract. Antimicrobial activity was determined by measuring diagonally the diameter of clear zones of inhibition in $\mathrm{mm}$ using a calibrated transparent rule. Organisms that showed clear zones were measured and recorded.

\section{Results and Discussion}

Table 1 shows antibacterial inhibitory activities of ethanol extract of Phyllanthus amarus on some clinical bacterial isolates of E. coli, Klebsiella, Pseudomonas, Citrobacter, Bacillus and Staph. aureus. Klebsiella showed a better sensitivity of $15.3333 \mathrm{~mm}$ at a concentration of $100 \mathrm{mg} / \mathrm{ml}$ followed by Bacillus which showed sensitivity of $14.6667 \mathrm{~mm}$ at $100 \mathrm{mg} / \mathrm{ml}$ and Klebsiella again showed a good sensitivity of $14.0000 \mathrm{~mm}$ at $75 \mathrm{mg} / \mathrm{ml}$, while the least antibacterial sensitive of $7.0000 \mathrm{~mm}$ was record at concentration of $3.125 \mathrm{mg} / \mathrm{ml}$. When compared to the negative control of $0.0000 \pm 0.0000^{\mathrm{a}}$ and positive control. The test extracts was less sensitive when compared to the positive control with antibacterial activities ranging from $16.0000 \mathrm{~mm}$ to $17.3333 \mathrm{~mm}$.

Figures 1-4 in bar charts indicates the antifungal inhibitory activities of ethanolic extract of $P$. amarus on clinical fungal isolates of Aspergillus sp, Penicillium sp, Saccharomyces cerevisiae and Candida $s p$. In the different concentrations the different fungi showed various sensitivity which was represented in decreasing order as the concentrations of the extract decreases. At $100 \mathrm{mg} / \mathrm{ml}$, Penicillium, Saccharomyces, Candida and Aspergillus recorded sensitive values of $13.0000 \mathrm{~mm}$, $13.0000 \mathrm{~mm}, 12.3333 \mathrm{~mm}$, and $11.6667 \mathrm{~mm}$ respectively. At $75 \mathrm{mg} / \mathrm{ml}$, Penicillium, Candida, Saccharomyces and Aspergillus had sensitivity of $12.3333 \mathrm{~mm}, 12.0000 \mathrm{~mm}, 11.3333 \mathrm{~mm}$ and $10.3333 \mathrm{~mm}$ respectively. Also, at $50 \mathrm{mg} / \mathrm{ml}$, Candida, Penicillium, Saccharomyces and Aspergillus recorded sensitivity of $10.6667 \mathrm{~mm}, 10.3333 \mathrm{~mm}, 9.6667 \mathrm{~mm}$ and $9.6667 \mathrm{~mm}$ respectively, while at $25 \mathrm{mg} / \mathrm{ml}$, Aspergillus, Penicillium, Saccharomyces and Candida showed sensitivity of 10.0000 $\mathrm{mm}, 9.3333 \mathrm{~mm}, 9.3333 \mathrm{~mm}$ and $9.0000 \mathrm{~mm}$ respectively. At $12.5 \mathrm{mg} / \mathrm{ml}$, Aspergillus, Saccharomyces, Candida and Penicillium had sensitivity of $8.0000 \mathrm{~mm}, 8.6667 \mathrm{~mm}, 8.6667 \mathrm{~mm}$ and $9.3333 \mathrm{~mm}$ respectively. At $6.25 \mathrm{mg} / \mathrm{ml}$, Aspergillus, Candida, Penicillium and Saccharomyces indicated sensitivity of $8.0000 \mathrm{~mm}, 8.0000 \mathrm{~mm} 7.6667 \mathrm{~mm}$ and $7.3333 \mathrm{~mm}$ respectively. Finally at $3.125 \mathrm{mg} / \mathrm{ml}$, Aspergillus, Saccharomyces, Candida and Penicillium also recorded sensitivity of $7.0000 \mathrm{~mm}, 7.0000 \mathrm{~mm}, 7.0000 \mathrm{~mm}$ and $6.6667 \mathrm{~mm}$ respectively. The antifungal activity when compared to the negative concentrated of $0.0000 \mathrm{~mm}$ show no inhibition but when compared to the positive control, the antifungal activities of the clinical test organisms showed inhibitions below the positive control values which ranged from $16.0000 \mathrm{~mm}$ to $17.3333 \mathrm{~mm}$.

Figures 1-4 further shows the mean antifungal activities of ethanolic extract of Phyllanthus amarus on fungi species. Aspergillus sp., Pennicilium sp, Sacchromyces cerevisiae and Candida sp. with highest mean inhibition at $100 \mathrm{mg} / \mathrm{ml}$ when compared to the positive control. No inhibition was recorded at the negative control. 
Table 1: Antibacterial activities of ethanolic extract of Phyllanthus amarus against oral pathogens

\begin{tabular}{|c|c|c|c|c|c|c|c|c|c|}
\hline \multirow{2}{*}{$\begin{array}{l}\text { EEC } \\
\mathrm{mg} / \mathrm{ml}\end{array}$} & \multicolumn{9}{|c|}{ Zone of Inhibition (mm) } \\
\hline & E. coli & $\begin{array}{l}\text { Klebsiella } \\
\text { pneumoniae. }\end{array}$ & $\begin{array}{l}\text { Pseudomonas } \\
\text { aeruginosa. }\end{array}$ & Citrobacter sp & & $\begin{array}{l}\text { Bacillus } \\
\text { subtilis. }\end{array}$ & & Staph. Aureus & \\
\hline 100 & $\begin{array}{l}12.3333 \pm \\
0.3333^{\mathrm{g}}\end{array}$ & $\begin{array}{l}15.3333 \pm \\
0.8819^{\mathrm{gh}}\end{array}$ & $\begin{array}{l}11.6667 \pm \\
0.8819^{c}\end{array}$ & $\begin{array}{l}11.0000 \\
0.5774^{\mathrm{d}}\end{array}$ & \pm & $\begin{array}{l}14.6667 \\
0.3333^{\text {ef }}\end{array}$ & \pm & $\begin{array}{l}12.0000 \\
0.5774^{\mathrm{d}}\end{array}$ & \pm \\
\hline 75 & $\begin{array}{l}10.6667 \pm \\
0.3333^{\mathrm{f}}\end{array}$ & $\begin{array}{l}14.0000 \pm \\
0.5774^{\mathrm{fg}}\end{array}$ & $\begin{array}{l}12.0000 \pm \\
1.1547^{\mathrm{c}}\end{array}$ & $\begin{array}{l}11.0000 \\
1.1547^{\mathrm{d}}\end{array}$ & \pm & $\begin{array}{l}14.0000 \\
0.5774^{\mathrm{e}}\end{array}$ & \pm & $\begin{array}{l}11.6667 \\
1.2019^{\mathrm{cd}}\end{array}$ & \pm \\
\hline 50 & $\begin{array}{l}10.0000 \pm \\
0.5774^{\text {ef }}\end{array}$ & $\begin{array}{l}13.3333 \pm \\
0.3333^{\text {ef }}\end{array}$ & $\begin{array}{l}11.3333 \pm \\
0.6667^{\mathrm{c}}\end{array}$ & $\begin{array}{l}10.6667 \\
0.3333^{d}\end{array}$ & \pm & $\begin{array}{l}13.3333 \\
0.6667^{\mathrm{de}}\end{array}$ & \pm & $\begin{array}{l}11.0000 \\
0.5774^{\mathrm{bcd}}\end{array}$ & \pm \\
\hline 25 & $\begin{array}{l}9.0000 \pm \\
0.5774^{\mathrm{de}}\end{array}$ & $\begin{array}{l}12.0000 \pm \\
0.5774^{\mathrm{de}}\end{array}$ & $\begin{array}{l}10.3333 \pm \\
0.3333^{\mathrm{bc}}\end{array}$ & $\begin{array}{l}10.0000 \\
0.5774^{\mathrm{d}}\end{array}$ & \pm & $\begin{array}{l}12.0000 \\
0.5774^{\mathrm{d}}\end{array}$ & \pm & $\begin{array}{l}11.0000 \\
0.5774^{\text {bcd }}\end{array}$ & \pm \\
\hline 12.5 & $\begin{array}{l}8.6667 \pm \\
0.3333^{\text {cd }}\end{array}$ & $\begin{array}{l}10.6667 \pm \\
0.3333^{\mathrm{cd}}\end{array}$ & $\begin{array}{l}10.0000 \pm \\
0.5774^{\mathrm{bc}}\end{array}$ & $\begin{array}{l}9.3333 \\
0.8819^{\mathrm{cd}}\end{array}$ & \pm & $\begin{array}{l}10.3333 \\
0.3333^{c}\end{array}$ & \pm & $\begin{array}{l}9.6667 \\
0.3333^{b c}\end{array}$ & \pm \\
\hline 6.25 & $\begin{array}{l}7.6667 \pm \\
0.3333^{\mathrm{bc}}\end{array}$ & $\begin{array}{l}9.6667 \pm \\
0.3333^{\mathrm{bc}}\end{array}$ & $\begin{array}{l}8.6667 \pm \\
0.8819^{\mathrm{b}}\end{array}$ & $\begin{array}{l}8.0000 \\
0.5774^{b c}\end{array}$ & \pm & $\begin{array}{l}10.0000 \\
1.1574^{\mathrm{c}}\end{array}$ & \pm & $\begin{array}{l}9.3333 \\
0.8819^{\mathrm{b}}\end{array}$ & \pm \\
\hline 3.125 & $\begin{array}{l}7.0000 \pm \\
0.5774^{\mathrm{b}}\end{array}$ & $\begin{array}{l}8.6667 \pm \\
0.3333^{\mathrm{b}}\end{array}$ & $\begin{array}{l}8.6667 \pm \\
0.88192^{b}\end{array}$ & $\begin{array}{l}7.3333 \\
0.3333^{b}\end{array}$ & \pm & $\begin{array}{l}8.3333 \\
0.3333^{b}\end{array}$ & \pm & $\begin{array}{l}9.0000 \\
0.5774^{\mathrm{b}}\end{array}$ & \pm \\
\hline $\begin{array}{l}\text { Negative } \\
\text { Control }\end{array}$ & $.0000 \pm 0.0000^{\mathrm{a}}$ & $.0000 \pm 0.0000^{\mathrm{a}}$ & $.0000 \pm 0.0000^{\mathrm{a}}$ & $.0000 \pm 0.0000$ & & $.0000 \pm 0.000$ & & $.0000 \pm 0.0000^{\mathrm{a}}$ & \\
\hline $\begin{array}{l}\text { Positive } \\
\text { Control }\end{array}$ & $\begin{array}{l}16.6667 \pm \\
0.3333^{\mathrm{h}}\end{array}$ & $\begin{array}{l}16.6667 \pm \\
0.3333^{\mathrm{h}}\end{array}$ & $\begin{array}{l}17.3333 \\
0.3333^{\mathrm{d}}\end{array}$ & $\begin{array}{l}17.3333 \\
0.3333^{\mathrm{e}}\end{array}$ & \pm & $\begin{array}{l}16.0000 \\
0.0000^{f}\end{array}$ & \pm & $\begin{array}{l}16.6667 \\
0.3333^{\mathrm{e}}\end{array}$ & \pm \\
\hline
\end{tabular}

Mean values \pm SEM with different superscript alphabets along the same row are significantly different from each other $(\mathrm{P}<0.05)$

$\mathrm{EEC}=$ Ethanolic Extract Concentrations

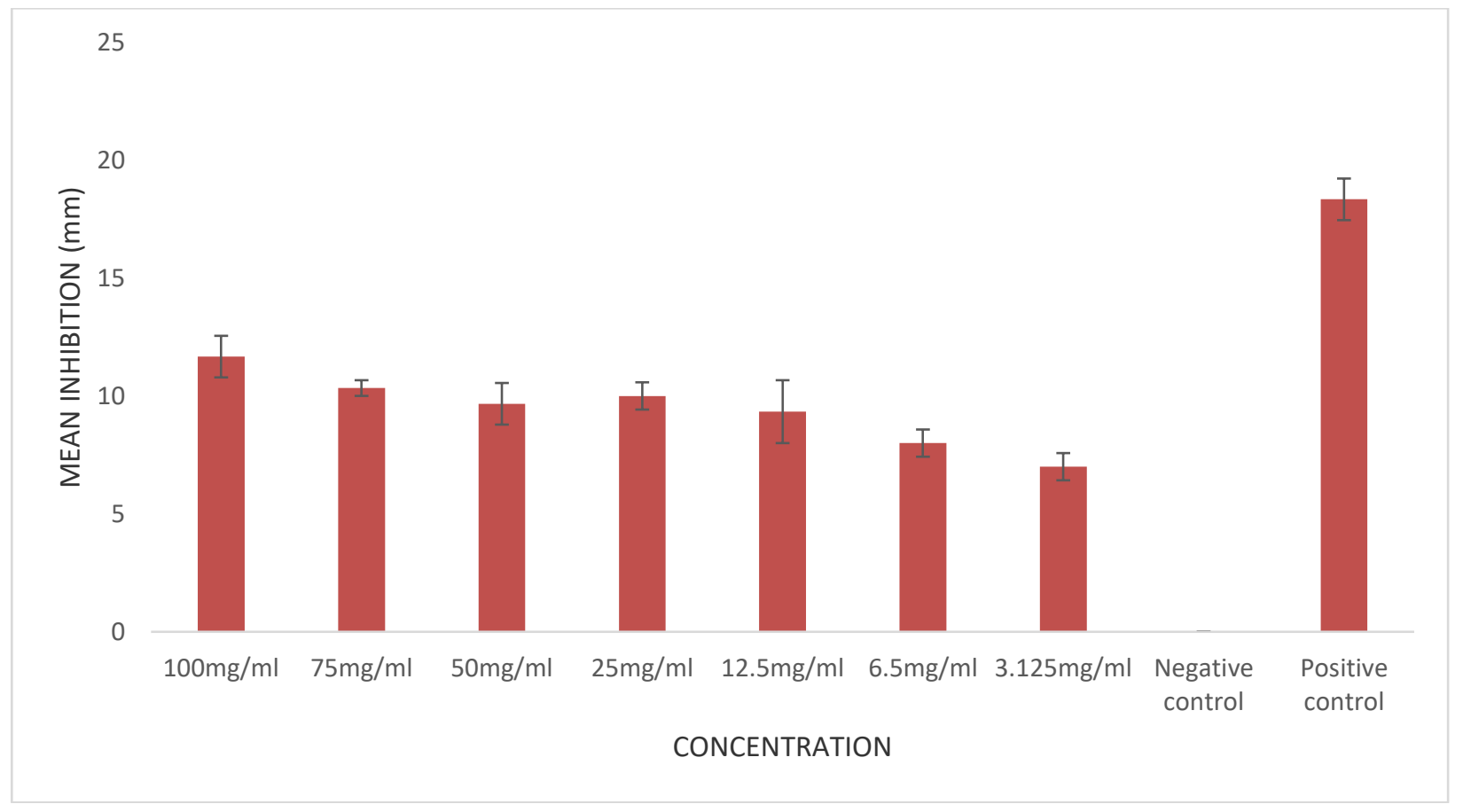

Figure 1: Antifungal inhibitory activities of ethanolic extract of Phyllanthus amarus on Aspergillus $\mathrm{sp}$ 


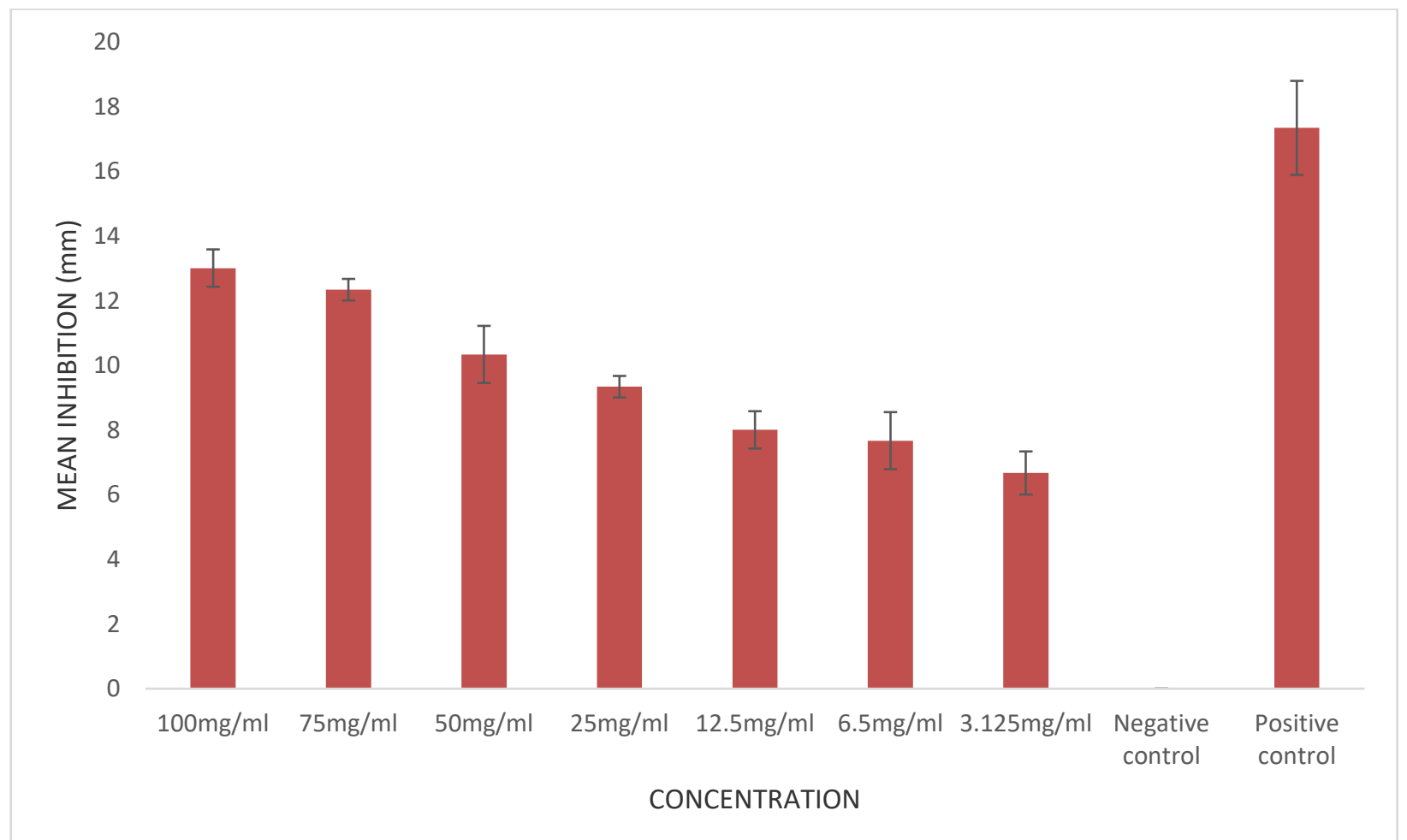

Figure 2: Antifungal inhibitory activities of ethanolic extract of Phyllanthus amarus on Penicillium sp.

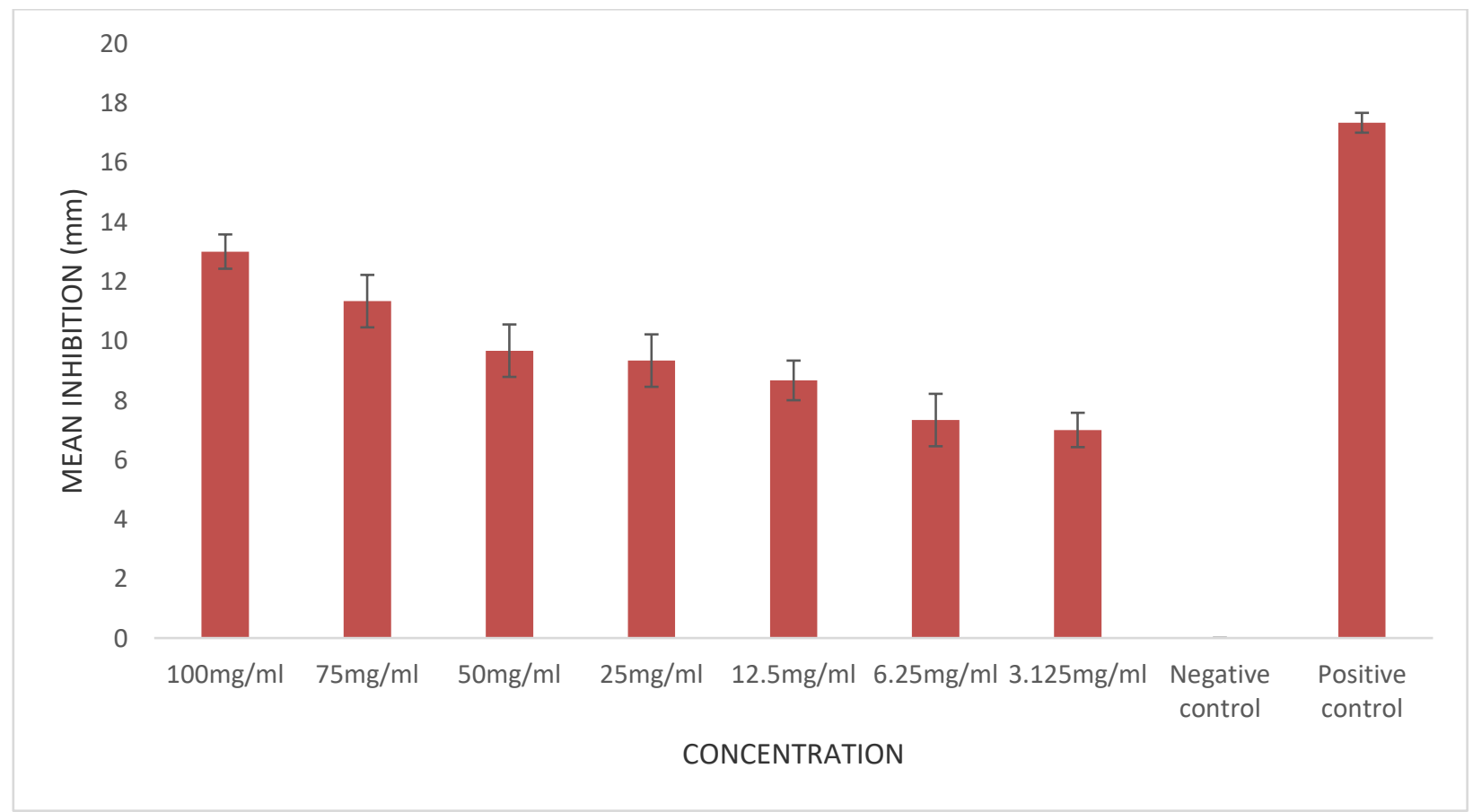

Figure 3: Antifungal inhibitory activities of ethanolic extract of Phyllanthus amarus on Sacchoromyces $\mathrm{sp}$. 


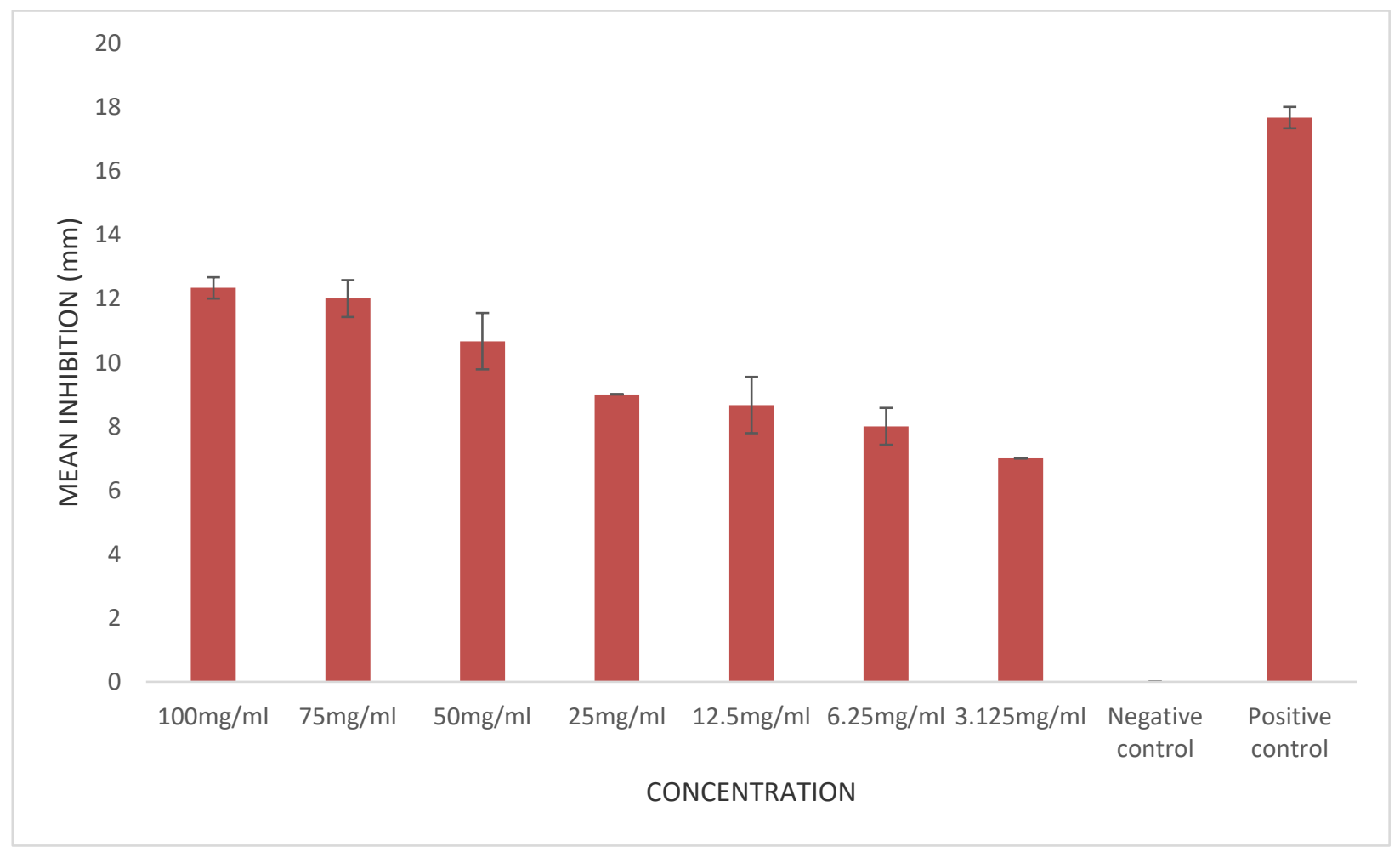

Figure 4: Antifungal inhibitory activities of ethanolic extract of Phyllanthus amarus on Candida sp

Phyllanthus amarus is used as diuretic, stomachic and antiseptic in traditional medicine. The fresh leaves and roots are used in the treatment of jaundice and digestive troubles. The plant is also used in treatment of dental disease in folk medicine. The plant has not yet been evaluated for antimicrobial activity against dental infectious disease. Hence, the current study was aimed at investigating the antimicrobial sensitivity of ethanol extract of Phyllanthus amarus (Schum. et Thonn) leaves on oral microorganisms. The ethanolic extract of $P$. amarus leaves showed appreciable antibacterial and antifungal activities against selected bacteria. The values of different inhibitory concentration ranged from 3.125 to $100 \mathrm{mg} / \mathrm{ml}$. These effects were particularly observed against gram positive bacteria such as Staphylococcus aureus, Bacillus subtilis and gram negative bacteria such as Escherichia coli, Pseudomonas aeruginosa, K. pneumoniae and Citrobacter sp. The leaf extract indicated higher inhibitory activity in gram negative bacteria such as $K$. pneumonae compared to gram positive bacteria such as $B$. subtilis. This finding is similar to the result obtained by [10] which showed that the extract of $P$. amarus has more inhibitory effect on gram positive organisms than the gram negative organisms. The leaf extract also showed higher inhibitory activity in some fungi species such as Penicillium and Sacchromyces. P. amarus can help control infections caused by $S$. aureus which is a major pathogen of human infections varying from food poisoning or minor skin infections to severe life threatening infections such as septicaemia and E. coli which causes Urinary Tract Infection (UTI), diarrhea, sepsis and meningitis [11]. The ethanolic leaf extract of $P$. amarus in this study showed antimicrobial activity against all the bacterial and fungal species used. The extract showed significant inhibitory effect against all the clinically important bacteria organisms such as Escherichia coli, Pseudomonas aeruginosa, Klebsiella pneumoniae, Citrobacter sp, Bacillus subtilis and Staphylococcus aureus, and fungi species such as Aspergillus sp, Penicillin $\mathrm{sp}$, Saccharomyces cerevisae and Candida sp. This could be probably due to the phyto-constituents present in the extract. 
Oshomoh, E. O. et al. / NIPES Journal of Science and Technology Research 2(3) 2020 pp. $96-102$

\section{Conclusion}

The results confirmed the use of the plant in traditional medicine for malaria, typhoid fever, jaundice, diabetes, stomach-ache and kidney problems. Therefore, the leaf extract and other plant parts could be isolated, purified, concentrated and individually tested to identify the specific bioactive element(s) responsible for the antimicrobial activity and other health benefits of the plant.

\section{References}

[1] Sonia, V., Hitender, S. and Munish, G. (2014). Phyllanthus amarus: A Review Journal of Pharmacognosy and Phytochemistry 3(2): 18-22

[2] Morton, J. F. (2008). Atlas of Medicinal Plants of Middle America. Library of Congress Cataloging in Publication Data. Thomas books, $1420 \mathrm{pp}$.

[3] Dhir H., Roy A. K., Sharma A. and Talukder G. (2002). Protection afforded by aqueous extracts of Phyllanthus species against cytotoxicity induced by lead and aluminium salts. Phytotherapy Research 4: 172-176.

[4] Meena J.; Sharma R.A. and Rolania R. (2018). A review on phytochemical and pharmacological properties of phyllanthus amarus schum. And thonn. International journal of pharmaceutical sciences and research. 1: 83-86.

[5] Devi S., Kumar D. and Kumar M. (2016). In-Vitro antioxidant activities of methanolic extract of whole plant of Phyllanthus amarus (Euphorbiaceae). International Journal Botany Study.1: 30-32.

[6] Devi S., Kumar M. (2017) In vitro Antioxidant potential of methanolic extract of whole plant of Phyllanthus amarus Schum (Euphorbiaceae). International Journal Botany Study 2: 100-102.

[7] Chandewar, A. and Dhongade, H. (2013). Pharmacognostical and Phytochemical studies of Phyllanthus amarus leaves. International Journal of Biomedical and Advance Research 4: 383-410.

[8] Adegoke, A. A., Iberi, P. A., Akinpelu, D. A. and Aiyegoro, P. (2010). Studies on phytochemical screening and antimicrobial potentials of Phyllanthus amarus against multiple antibiotic resistant bacteria. International Journal of Applied Research in Natural Products 3: 6.

[9] Karthikeyan K. and Kulothungan S. (2014). Phytochemical, pharmacological, in vitro propagation and molecular studies on Phyllanthus niruri L. http://hdl.handle.net/123456789/15143.

[10] Dhandapani R., Lakshmi D., Balakrishnan V. and Jayakumar S. (2007). Preliminary phytochemical investigation and antibacterial activity of Phyllanthus amarus Schum \& Thorn. Ancient science of life. 27 (1):1.

[11] Arun T, Senthilkumar B, Purushothaman K, Aarthy A. (2012). GC-MS Determination of Bioactive Components of Phyllanthus amarus (L.) and its Antibacterial Activity. Journal of Pharmacy Research. 5(9), 4767-4771 4767-4771. Research Article ISSN: 0974-6943.Department of Biotechnology, Muthayammal College of Arts and Science, Rasipuram-637 408, Tamil Nadu, India. 